\title{
Pengaruh tingkat kepadatan tanaman terhadap pertumbuhan Sorgum Brown Mid Rib (BMR) yang diberi pupuk bokashi kotoran ayam pada kondisi ternaung
}

\author{
S.W. Lundeto, S.D. Anis*, W.B. Kaunang, C.I.J. Sumolang \\ Fakultas Peternakan Universitas Sam Ratulangi Manado, 95115 \\ *Korespondensi (corresponding author): selvi_anis@yahoo.com
}

\begin{abstract}
ABSTRAK
Penelitian ini bertujuan untuk mengetahui pengaruh tingkat kepadatan populasi terhadap pertumbuhan sorgum BMR yang diberi pupuk bokashi kototran ayam pada kondisi ternaung. Penelitian ini menggunakan rancangan acak lengkap (RAL) yang terdiri dari 4 perlakuan dan 7 ulangan sehingga terdapat 28 satuan percobaan. Perlakuan yang diberikan yaitu tingkat

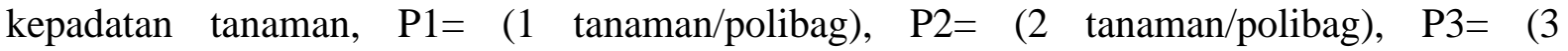
tanaman/polibag), dan $\mathrm{P} 4=(4$ tanaman/polibag $)$. Variabel pertumbuhan yang diamati yaitu tinggi tanaman, panjang daun, dan jumlah daun. Hasil analisis keragaman menunjukkan bahwa perlakuan tingkat kepadatan populasi memberi pengaruh yang berbeda sangat nyata $(\mathrm{P}<0,01)$ terhadap tinggi tanaman, panjang daun, dan jumlah daun. Uji lanjut $\mathrm{BNJ}$ menunjukkan bahwa tingkat kepadatan 1 tanaman/polybag memberikan tinggi tanaman, jumlah daun dan panjang daun yang tertinggi. Berdasarkan hasil penelitian disimpulkan bahwa tingkat kepadatan P1 (1 tanaman/polybag) memberikan hasil yang terbaik untuk pertumbuhan tanaman sorgum BMR.
\end{abstract}

Kata kunci : Kepadatan, pertumbuhan, sorgum.

\begin{abstract}
THE IMPACT OF PLANT'S DENSITY ON THE GROWTH OF SORGHUM BROWN MID RIB WITH CHICKEN MANURE FERTILIZER IN AN ELEVATED STATE. The purpose of this research was determines growth of sorghum BMR with different population density use chicken manure fertilizer in an elevated state. This experiment was conducted using Completely Randomized Design (CRD). The treatment consisted of four planting density, $(\mathrm{P} 1=(1$ plant/Polybag) $\mathrm{P} 2=(2$ plants/polybag $) \mathrm{P} 3=(3$ plants/polybag) $\mathrm{P} 4=(4$ plants/polibag), each treatment had seven replications. Data were analyzed using analysis of variance and HSD test. The variables measured were growth that are plant's height, leaf length, and number of leaves. The results showed that different planting population were significant different $(\mathrm{P}<0.01)$ on plant's height, leaf length, and number of leaves. HSD test showed that planting population $\mathrm{P} 1=(1$ plant/Polybag $)$ were significant $(\mathrm{P}<0.01)$ have higher plant's height, leaf length, and number of leaves than $\mathrm{P} 3=(3$ plants/polybag) and $\mathrm{P} 4=(4$ plants/polybag $)$. It can be concluded that planting density $\mathrm{P} 1=(1$ plant/Polybag) have the highest growth of sorghum BMR that were highest plant's height, leaf length, and number of leaves.
\end{abstract}

Key words: Density, Growth, Sorghum. 


\section{PENDAHULUAN}

Hijauan merupakan sumber utama pakan ternak ruminansia yang di gunakan untuk hidup pokok dan produksi. Oleh sebab itu, kualitas, kuantitas dan kontinuitas hijauan perlu diperhatikan. Salah satu hijauan pakan ternak yang berpotensi dikembangkan di Indonesia yaitu tanaman sorgum. Sorgum merupakan salah satu tanaman serealia yang termasuk dalam family Gramineae yang hidup di daerah tropis. Sorgum telah banyak di kembangkan di Negara-negara Afrika, Asia dan Amerika. Menurut Godoy dan Tesso (2013), sorgum memiliki daya adaptasi yang cukup baik pada kondisi lahan marginal. Tanaman sorgum juga memiliki kelebihan dapat di panen 2-3 kali dalam sekali tanam. Sorgum merupakan tanaman penghasil pakan hijauan sekitar 15-20 ton/ha/thn dan pada kondisi optimum dapat mencapai 30-40 ton/ha/thn dalam bentuk bahan segar. Kandungan nutrisi biji sorgum berdasarkan 100\% bahan kering berupa protein $10,26 \%$, serat kasar 2,72\%, lemak 2,70\%, Ca 0,93\% dan P 0,38\% (Rumambi, 2012). Produksi sorgum di Indonesia masih rendah yaitu sekitar 13 ton/ha/thn. Vasilakoglou et al. (2011) tanaman ini memiliki daya adaptasi yang cukup baik pada kondisi lahan marginal.

Salah satu alternatif untuk meningkatkan produktivitas sorgum yaitu meningkatkan kesuburan tanah dengan pemupukan. Tanaman yang tumbuh pada tanah yang kurang unsur hara, akan menyebabkan lambatnya pertumbukan (Dewanto et al., 2013). Pupuk kandang dapat menambah tersedianya unsur hara bagi tanaman. Selain itu pupuk kandang mempunyai pengaruh yang positif terhadap sifat fisik dan kimiawi tanah, mendorong perkembangan jasat renik. (Akbar dan Pinta, 2017) menyatakan tanaman yang diberikan pupuk organik akan memiliki akumulasi biomassa bagian atas dari tanaman yang banyak dibandingkan degan tanaman yang diberikan pupuk sintetis. Pemberian bahan organik bertujuan untuk memperbaiki struktur tanah, meningkatkan kapasitas menahan air, dan meningkatkan kegiatan biologi tanah (Dinesh et al., 2010). Hasil penelitian Pangaribuan (2011) juga menunjukkan bahwa pupuk organik limbah tanaman juga dapat mengurangi pemakaian pupuk anorganik. Bahan organik yang memiliki rasio $\mathrm{C} / \mathrm{N}$ sama dengan tanah memungkinkan bahan tersebut dapat diserap oleh tanaman (Djuarnani et al., 2005). Pupuk kandang ayam memiliki kandungan unsur hara $\mathrm{N}, \mathrm{P}$ dan $\mathrm{K}$ yang lebih banyak dari pada pupuk kandang jenis ternak lainnya (Tabel 1). Nitrogen merupakan salah satu faktor kunci yang membatasi pertumbuhan dan perkembangan tanaman (Ferguson et al., 2010), serta merupakan unsur hara utama untuk pertumbuhan tanaman, yang pada umumnya sangat diperlukan pembentukan bagian-bagian fegetatif tanaman seperti daun, batang dan akar. Namun kelebihan pupuk yang mengandung unsur $\mathrm{K}$ dapat meningkatkan kandungan oxalate larut pada rumput dan dapat bersifat racun bagi ternak (Rahman et al., 2010). membantu mengedarkan karbohidrat, serta mempercepat metabolisme unsur nitrogen. Tanaman yang kekurangan unsur nitrogen juga dapat menyebabkan dan berkadar serat kasar tinggi, hal ini dikarenakan menebalnya membran sel daun sedangkan sel sendiri berukuran kecil-kecil (Sutejo dan Kastasapoetra, 1998 disitasi Bandu et al., 2018)

Kepadatan tanaman merupakan salah satu faktor penting dalam usaha meningkatkan hasil panen. Pada populasi optimal, kompetisi antara tanaman masih terjadi sehingga pertumbuhan dan hasil per individu menjadi berkurang. Tanaman pada dasarnya bila tumbuh dalam satu komunitas selalu diperhadapkan dengan kompetisi. Pengaturan jarak tanam juga merupakan salah satu faktor yang harus diperhatikan untuk mendapatkan pertumbuhan dan produksi yang optimal. 
Tabel 1. Analisis Bokashi Limbah Sesudah Pengomposan (Hartatik dan Widowati, 2006)

\begin{tabular}{llllllll}
\hline \multirow{2}{*}{ Perlakuan } & $\mathrm{N}$ total & $\mathrm{P}$ bray & $\mathrm{K}(\%)$ & \multicolumn{2}{c}{$\mathrm{pH} \mathrm{1:2,5}$} & C-organik & $\mathrm{C} / \mathrm{N}$ \\
\cline { 5 - 6 } & $(\%)$ & $(\%)$ & & $\mathrm{H}_{2} \mathrm{O}$ & $\mathrm{KCl}$ & $(\%)$ & \\
\hline Bokasi pakan ayam & 1,3 & 1,21 & 1,39 & 8,65 & 7,99 & 7,84 & 6,03 \\
Bokasi kotoran kambing & 1,12 & 0,32 & 1,07 & 8,85 & 8,07 & 9,03 & 8,06 \\
Bokasi kotoran sapi & 0,95 & 0,18 & 0,58 & 7,55 & 6,85 & 11,93 & 12,56 \\
\hline
\end{tabular}

Jarak tanam akan mempengaruhi efisiensi penggunaan cahaya, kompetisi antar tanaman dalam penggunaan air dan unsur hara yang akan mempengaruhi hasil (Silaban et al., 2013). Adanya kecenderungan penurunan hasil disebabkan populasi yang tinggi, meningkatnya persaingan antara tanaman itu sendiri dalam memperoleh hara, air dan cahaya matahari. bahwa tingkat kepadatan populasi sangat berpengaruh terhadap pertumbuhan sorgum BMR (Lilhaq et al., 2018). Naungan dapat mempengaruhi perkecambahan dan pertumbuhan tanaman hijauan pakan, namun tanaman memiliki kelenturan fenotipik sebagai adaptasi tanaman rumput terhadap keterbatasan cahaya terekspresi perubahan-perubahan pada karakter daun seperti pengurangan massa daun per satuan luas daun, pengurangan respirasi gelap dan titik konpensasi cahaya (Vinocur and Ritchie, 2001)

\section{MATERI DAN METODE PENELITIAN}

\section{Tempat dan waktu penelitian}

Penelitian ini telah dilaksanakan di lahan Fakultas Peternakan UNSRAT Manado pada tanggal 23 Januari sampai 23 Mei 2017.

\section{Bahan dan alat}

Penelitian ini menggunakan bahan dan alat sebagai berikut:

Bahan: EM4, bibit Sorgum BMR, kotoran ternak ayam (feses), gula putih, molases, air sumur, kulit kopi, dedak halus, dan tanah sebagai media tanam.

Alat: Cangkul, parang, meteran, gergaji, bambu, polibag berdiameter $30 \mathrm{~cm}$, thermometer, kamera, dan ATK.

\section{Metode penelitian}

Metode penelitian ini menggunakan Rancangan Acak Lengkap (RAL) (Steel and Torrie, 1995) terdiri dari :

P1 : satu tanaman/polybag

P2 : dua tanaman/polybag

P3 : tiga tanaman/polybag

P4 : empat tanaman/polybag

Setiap perlakuan terdiri dari 7 ulangan sehingga diperoleh 28 satuan pengamatan. Untuk analisis data menggunakan program excell 2007 dan minitab versi 16 .

\section{Prosedur Penelitian}

Prosedur pembuatan pupuk bokashi kotoran ayam yaitu dengan mengikuti prosedur menurut Kusuma (2012);

1. Pembuatan pupuk bokashi kotoran ayam.

Persiapan bahan terdiri dari larutan EM4 + gula + air secukupnya. Penyiapan bahan pengisi kotoran ayam $(100 \mathrm{~kg})$, dedak halus $(10 \mathrm{~kg})$, serbuk kopi $(60 \mathrm{~kg})$ sekam padi (20 kg) air secukupnya. Proses pembuatannya semua bahan dicampur secara homogen lalu di tutup menggunakan karung goni. Pengecekan suhu dilakukan setiap 5-6 jam sekali apa bila terjadi peningkatan suhu pada bahan pengolahan, maka dilakukan pembokaran dengan cara membolak balikan bahan tersebut dengan tujuan agar terjadi penurunan suhu, kemudian ditutup selama 2-4 minggu. Pupuk sudah dapat di gunakan apabila memiliki ciri berwarnah hitam, gembur, tidak panas dan tidak terlalu berbau

2. Penyediaan tanah

Tanah yang digunakan yaitu dikeringkan, anginkan terlebih dahulu selama 1 minggu setelah itu tanah di beri pupuk $400 \mathrm{~g}$ dan dibiarkan lagi 1 minggu 
supaya tanah dekomposisi secara sempurna.

3. Penyediaan polybag berdiameter $30 \mathrm{~cm}$ sebanyak 28 buah. Polybag di isi dengan tanah sebanyak $4 \mathrm{~kg}$, kemudian di tambah bokashi kotoran ayam $400 \mathrm{~g}$

4. Penanaman biji sorgum disemaikan terlebih dahulu selama 10 hari sampai kecambah muncul di atas permukaan tanah, barulah bibit dipilih dan dipindahkan ke polybag. Jumlah bibit sorgum BMR ditanam melebihi perlakuan yang ditetapkan. Benih ditanam kedalaman $3 \mathrm{~cm}$ dibawah tanah. Pengukuran dilakukan setiap minggu dan pembersihan gulma dilakukan setiap hari.

5. Penyiraman tanaman dilakukan jam 06;00 pagi dan 17;00 sore. Pemberian air sebanyak $240 \mathrm{~mL} /$ polybag

6. Pengukuran tinggi tanaman $(\mathrm{cm})$, panjang daun $(\mathrm{cm})$ dan jumlah daun (helai) dilakukan setiap minggu selama 6 minggu

\section{Variabel yang diukur}

1. Tinggi tanaman $(\mathrm{cm})$ diukur mulai dari permukaan tanah sampai pada bagian ujung daun

2. Panjang daun $(\mathrm{cm})$ diukur mulai dari pangkal hingga ujung daun, mengikuti tulang daun utama, pengukuran pertama dilakukan 1 minggu setelah penyiapan

3. Jumlah daun (helai) Jumlah daun yang dihitung meliputi keseluruhan daun yang berada di setiap pohon sorgum, dihitung selama empat minggu

\section{HASIL DAN PEMBAHASAN}

Pengaruh perlakuan tingkat kepadatan tanaman yang diberikan pupuk bokashi kotoran ayam pada kondisi ternaung terhadap panjang daun, jumlah daun, dan tinggi tanaman sorgum BMR dapat dilihat pada Tabel 2.

\section{Tinggi tanaman}

Tinggi tanaman sorgum BMR berkisar antara 108,27 cm sampai dengan $133,80 \mathrm{~cm}$ (dapat dilihat pada Tabel 2).
Hasil ini lebih tinggi dibanding dengan penelitian yang dilakukan oleh Lilhaq et al. (2018), untuk tingkat kepadatan 1 tanaman/polybag tinggi tanaman hanya mencapai $122,33 \mathrm{~cm}$, dan hamper sama dengan hasil penelitian Silalahi et al. (2018) bahwa tinggi tanaman sorgum berkisar 107,2 cm sampai dengan 120,0 $\mathrm{cm}$.

Hasil analisis keragaman menunjukkan bahwa pengaruh perlakuan kepadatan populasi memberikan pengaruh yang berbeda sangat nyata $(\mathrm{P}<0.01)$ terhadap tinggi tanaman. Hasil uji lanjut dengan BNJ menunjukkan bahwa perlakuan P1 (1 tanaman/polybag) berbeda sangat nyata $(\mathrm{P}<0,01)$ dengan perlakuan P4 (4 tanaman/polybag), dan memberikan pengaruh yang berbeda tidak nyata $(\mathrm{P}>0,05)$ dengan perlakuan P3 (3 tanaman/polybag) dan P2 (2 tanaman/polybag).

Hasil penelitian ini menunjukkan bahwa semakin tinggi tingkat kepadatan populasi tanaman sorgum BMR, maka semakin menurunnya produktivitas tanaman, terutama pada tinggi tanaman sorgum BMR. Hal ini diduga disebabkan terjadinya persaingan didalam penyerapan unsur hara, air, cahaya matahari, antara tanaman itu sendiri.

Hasil penelitian ini sejalan dengan laporan Lilhaq et al. (2018), bahwa tingkat kepadatan populasi sangat berpengaruh terhadap pertumbuhan sorgum BMR dimana 1 tanaman/polybag menunjukkan perbedaan tinggi tanaman sorgum BMR paling tertinggi yaitu mencapai (122,33 $\mathrm{cm})$ tinggi tanaman. Selanjutnya diberi perlakuan yang semakin tinggi yakni pada perlakuan 6 tanaman/polybag memperoleh hasil tinggi tanaman yang semakin rendah yaitu hanya mencapai tinggi $(114,12 \mathrm{~cm})$.

Menurut Wynne et al. (1974) yang disitasi Silaban (1994), Adanya kecenderungan penurunan hasil disebabkan populasi yang tinggi, menyebabkan terjadinya peningkatan persaingan antara tanaman itu sendiri 
Tabel 2. Pengaruh Perlakuan Terhadap Panjang Daun, Jumlah Daun, Dan Tinggi Tanaman Sorgum BMR

\begin{tabular}{llll}
\hline Perlakuan & Tinggi Tanaman $(\mathbf{c m})$ & $\begin{array}{l}\text { Jumlah } \\
\text { Daun (helai) }\end{array}$ & $\begin{array}{l}\text { Panjang } \\
\text { Daun }(\mathbf{c m})\end{array}$ \\
\hline P1 & $133.80^{\mathrm{a}}$ & $9.86^{\mathrm{a}}$ & $82.80^{\mathrm{ab}}$ \\
P2 & $126.64^{\mathrm{ab}}$ & $8.64^{\mathrm{ab}}$ & $88.24^{\mathrm{a}}$ \\
P3 & $114.09^{\mathrm{ab}}$ & $7.43^{\mathrm{b}}$ & $76.55^{\mathrm{ab}}$ \\
P4 & $108.27^{\mathrm{b}}$ & $7.32^{\mathrm{b}}$ & $70.22^{\mathrm{b}}$ \\
\hline
\end{tabular}

Keterangan: Nilai pada lajur yang sama dengan superskrip yang berbeda menunjukkan perbedaan yang nyata $(\mathrm{P}<0,01)$

dalam memperoleh hara, air, cahaya matahari.

\section{Panjang daun}

Panjang daun $(\mathrm{cm})$ diukur mulai dari pangkal hingga ujung daun, mengikuti tulang daun utama. Panjang daun tanaman sorgum BMR berkisar antara 70,22 cm sampai dengan $82,80 \mathrm{~cm}$. Hasil ini sama dengan hasil penelitian Sriagtula dan Sowmen (2018) yang mendapatkan panjang daun sorgum BMR berkisar 69,27 cm sampai dengan $83,33 \mathrm{~cm}$.

Hasil analisis keragaman menunjukkan bahwa perlakuan tingkat kepadatan populasi memberikan pengaruh berbeda sangat nyata $(\mathrm{P}<0.01)$ terhadap panjang daun. Uji lanjut dengan Tuckey Simultaneous Test menunjukkan bahwa perlakuan P1 (1 tanaman/polybag) berbeda sangat nyata $(\mathrm{P}<0,01)$ lebih panjang dibandingkan dengan perlakuan P4 (4 tanaman/polybag) dan berbeda tidak nyata dengan perlakuan P3 (3 tanaman/polybag) dan P2 (2 tanaman/polybag).

Tanaman yang ditanam pada satu media tanam dengan tingkat kepadatan yang sangat tinggi akan mengakibatkan terjadinya persaingan penyerapan unsur hara, air, dan cahaya matahari sehingga dapat menyebabkan terhambatnya pertumbuhan dan perkembangan jaringan tumbuhan terutama pada daun, akar dan batang. Narayan et al. (2017) menyatakan bahwa persaingan akan terjadi apabila individu dari suatu kelompok tanaman hadir dalam suatu kelompok tanaman yang lain, sementara faktor lingkungan tumbuh berada pada kondisi terbatas. Keterbatasan lingkungan tumbuh, baik yang berada di atas tanah maupun di bawah tanah akan berdampak pada proses pertumbuhan dan perkembangan tanaman, terutama apabila ke dua faktor lingkungan tumbuh tersebut diperlukan pada waktu dan jumlah yang sama. Kompetisi yang terjadi antara tanaman budidaya dengan gulma terhadap air, cahaya dan $\mathrm{CO}_{2}$, nutrisi dan lahan dapat berupa intraspesifik (antara individu dalam satu populasi) maupun interspesifik (antara dua atau lebih populasi misalnya antara tanaman dan gulma) (Bomfrod, 2004). Kompetisi untuk cahaya dan karbondioksida sangat ditentukan oleh struktur kanopi dan luas wilayah fotosintesis; sedangkan kompetisi untuk air dan nutrisi sangat ditentukan oleh akivitas akar, pola disribusinya serta kemampuan menyerap air dan nutrisi. Kompetisi yang terjadi selama pertumbuhan fase vegetatif awal tidak terlalu berpengaruh tetapi seiring dengan pertambahan umur tanaman maka tingkat kompetisi semakin tinggi (Narayan et al., 2017).

\section{Jumlah daun}

Jumlah daun (helai) dihitung meliputi keseluruhan daun yg berada di setiap pohon sorgum. Jumlah daun tanaman sorgum BMR berkisar antara 7,32 helai sampai dengan 9,86 helai. Hasil ini hampir sama dengan hasil penelitian Telleng et al., (2015) yang mendapatkan jumlah daun 
sorgum berkisar 6,33 helai sampai 8,43 helai, dan lebih tinggi dari hasil penelitian Sriagtula et al., (2019) yang mendapatkan jumlah daun sorgum BMR berkisar 6,05 helai sampai dengan 7,18 helai.

Hasil analisis keragaman menunjukkan bahwa pengaruh perlakuan kepadatan populasi memberikan pengaruh yang berbeda sangat nyata $(\mathrm{P}<0.01)$ terhadap jumlah daun. Hasil uji lanjut dengan BNJ menunjukkan bahwa perlakuan P1 (1 tanaman/polybag) berbeda sangat nyata $(\mathrm{P}<0,01)$ dengan perlakuan P4 (4 tanaman/polybag) dan P3 (3 tanaman/polybag) namun memberikan pengaruh yang berbeda tidak nyata $(\mathrm{P}>0,05)$ dengan perlakuan P2 (2 tanaman/polybag). Hal ini diduga oleh adanya kompetisi penyerapan akan unsur hara, air dan cahaya matahari oleh tanaman itu sendiri. Sebagaimana penelitian yang dilaporkan oleh Lilhaq et al. (2018) semakin tinggi tingkat kepadatan tanaman maka semakin rendah hasil jumlah daun yang dimiliki oleh tanaman sorgum BMR.

Kepadatan tanaman juga berkaitan erat dengan jumlah cahaya matahari yang dapat diserap oleh tanaman, dimana tanaman yang mendapat cahaya matahari lebih akan bertumbuh lebih baik daripada tanaman yang ternaungi. Sudaryono (1996) menyatakan bahwa untuk pengembangan sorgum salah satu hal yang harus diperhatikan adalah jarak tanam sorgum. Sebagaimana diketahui bahwa Tanaman sorgum merupakan tipe tanaman C-4, dimana tanaman dengan tipe ini lebih suka terhadap penyinaran matahari. Tipe tanaman C-4 memiliki sel seludang berkas yang lebih tebal dibandingkan sel seludang berkas tanaman C-3 sehingga lebih banyak mengandung kloroplas, mitokondria, dan organel lain yang berperan sangat penting dalam proses fotosintesis (Salisbury dan Ross, 1995).

\section{KESIMPULAN}

Berdasarkan hasil penelitian ini dapat disimpulkan bahwa pada tingkat kepadatan P1 (1 tanaman/polybag) memberikan hasil yang terbaik untuk tinggi tanaman, jumlah daun, dan panjang daun.

\section{DAFTAR PUSTAKA}

Akbar, Y. dan Y. Pinta. 2017. Respon pertumbuhan dan hasil bawang merah (Alium ascalonikum L) pada beberapa media tanam. Jurnal Pertanian UMSB. 1(2):43-49

Bandu, V.S., D.A. Kaligis, R. Rustandi dan W.B. Kaunang. 2018. Pengaruh level pupuk bokashi kototran ayam terhadap pertumbuhan sorgum brown mid rib (BMR). Jurnal Zootek. 38(1): 77-83.

Dewanto, F.G., J.J.M.R. Londok, R.A.V. Tuturoong, W.B. Kaunang. 2013. Pengaruh pemupukan anorganik dan organik terhadap Produk Tanaman Jagung Sebagai sumber Pakan. Jurnal Zootek. 32(5):1-8

Dinesh, R., V. Srinivasan, S. Hamza, A. Manjusha. 2010. Short-term incorporation of organic manures and biofertilizers influences biochemical and microbial characteristics of soils under an annual crop turmeric (Curcuma longa L.). Bioresource Technology 101(12): 4697-4702

Djuarnani, N., Kristian dan Budi S. S. 2005. Cara cepat Membuat kompos. Agro Media Pustaka. Jakarta.

Ferguson, B.J., A. Indrasumunar, S. Hayashi, M.H. Lin, Y.H. Lin, D.E Reid dan P.M. Greshoff. 2010. Molecular analysis of legume nodule development and autoregulation. Journal of Integrative Plant Biology 52(1): 61-76.

Godoy, J.G.V. dan T.T. Tesso. 2013. Analysis of juice yield, sugar content, and biomas accumulation in 
sorghum. J Crop Sci. 53(4): 12881297.

Hartatik, W. dan L.R. Widowati. 2006. Pupuk Kandang. Balai Besar Litbang Sumber Daya Lahan Pertanian, Bahan Penelitian dan Pengembangan Pertanian, Bogor. Pp 59-82

Kusuma, M. E., 2012. Pengaruh beberapa jenis pupuk kandang terhadap kualitas bokashi. Jurnal Ilmu Hewan Tropika Vol 1. (2): 41-46

Lilhaq, O., D.A. Kaligis, Ch. L. Kaunang, Rustandi 2018. Pengaruh level bokashi kotoran ayam dan tingkat kepadatan populasi tanaman terhadap pertumbuhan vegetatif Sorgum Brown Midrib (BMR). Zootec 38(1): $37-43$

Narayan, S., M.I. Makhdoomi, A. Nabi, S.H. Khan, S. Mufti, B. Afroza, F. Mushtaq, K. Hussain dan F.A. Khan. 2017. Effect of plant spacing and pruning on growth and yield of cherry tomatoes under polyhouse condition in Kashmir. The Bioscan 12(1):359-361

Pangaribuan, D.A. 2011. Pengurangan pemakaian pupuk anorganik dengan penambahan bokashi serasah tanaman pada budidaya tanaman tomat. J. Agron. Indonesia 39(3):173-179

Rahman, M. M., Y. Ishii., M. Niimi dan O. Kawamura. 2010. Effects Combinet Of Nitrogen and Potassium fertilization on Oxalate content in Napiergrass (Penisetum Purpureum Schumach). Asian-Aust. Journal. Anim. Sci. 23(6): 719-723.

Rumambi, A. 2012. Penyediaan Pakan Berkelanjutan Melalui Inokulasi Fungi Mikoriza Arbuskula dan Aplikasi Fospat Alam pada Arachis pintoi cv Amarillo dalam Tumpang Sari dengan Jagung (Zea mays L) atau Sorgum (Sorghum bicolor L, Moench). Disertasi. Sekolah Pascasarjana. IPB. Bogor.

Salisbury, F. B. dan C. W. Ross. 1995. Fisiologi Tumbuhan. Jilid 1.
Bandung: Institut Teknologi Bandung.

Silaban, E., E. Purba dan J. Ginting. 2013. Pertumbuhan dan produksi jagung manis (Zea mays saccaratha S.) pada berbagai jarak tanam dan waktu olah tanah. Jurnal Agroteknologi 1(3):806-818.

Silalahi, M., A. Rumambi, M.M. Telleng dan W.B. Kaunang. 2018. Pengaruh pemberian pupuk kendang ayam terhadap ertumbuhan tanaman sorgum sebagai pakan. Zootec 38(2): $286-295$

Sriagtula, R. dan S. Sowmen. 2018. Evaluasi pertumbuhan dan produktivitas Sorgum Mutan Brown Midrib (Sorghum bicolor L. Moench) fase pertumbuhan berbeda sebagai pakan hijauan pada musim kemarau di Tanah Ultisol. Jurnal Peternakan Indonesia 20(2): 130-144

Sriagtula, R., S. Sowmen dan Q. Aini. 2019. Growth and productivity of Brown Midrib Sorghum Mutant Line Patir 3.7 (Sorghum bicolor L. Moench) treated with different levels of nitrogen fertilizer. Tropical Animal Science Journal 42(3): 209214

Steel, R. G. D. dan J. H. Torrie. 1995. Prinsip dan prosedur statistika: Suatu pendekatan Biometrik. Penerjemah: Sumantri, B. Gramedia Pustaka utama, Jakarta.

Sudaryono. 1996. Prospek sorgum di Indonesia: Potensi, peluang dan tantangan pengembangan agribisnis. Risalah Simposium Prospek Tanaman Sorgum untuk Pengembangan Agroindustri, 17-18 Januari 1995. Edisi Khusus Balai Penelitian Tanaman Kacangkacangan dan Umbi-umbian No. 41996: 25-38.

Telleng, M.M., L. Abdullah, I.G. Permana, P.D.M.H. Karti dan K.G. Wiryawan. 2015. Growth and Productivity of Different Sorghum Varieties Cultivated with Indigofera in 
Zootec Vol. 41 No. 1 : 158 - 165 (Januari 2021) pISSN 0852 - 2626 eISSN 2615 - 8698

Intercropping System. Proceeding of the 3rd International Seminar on Animal Industry, Bogor, 17-18 September 2015

Vasilakoglou, I., K. Dhima, N. Karagiannidis, T. Gatsis. 2011. Sweet sorghum productivity for biofuels under increaswd soil salinity and reduced irrigation. Field Crops Research. 120: 38-46

Vinocur, M. dan J. Ritchie. 2001.Mrize Leaf Development Bioses Coused By Air Temperature. Journal. agronomi 93:767-772. 